\title{
Studi Literatur Produksi Bioethanol dari Ampas Tebu dengan Metode Pyrolisis
}

\author{
Laily Agustina Rahmawati ${ }^{1}$ \\ ${ }^{1}$ Universitas Bojonegoro (laily.tiyangalit@gmail.com) \\ * Correspondence author: laily.tiyangalit@gmail.com; Tel.: - \\ Received: 10 Februari 2020; Accepted: 12 Maret 2020; Published: 13 Maret 2020
}

\begin{abstract}
Abstrak
Indonesia memiliki lahan tebu seluas sekitar 475.000 hektare dan produksi tebu lebih dari 33 juta ton per tahun, dengan hasil ampas tebu mencapai 10 juta ton per tahun, sehingga berpotensi untuk menghasilkan 2 milyar liter bioethanol dalam setahun. Ampas tebu diolah menjadi bioethanol dengan menggunakan metode pyrolysis, yang dipilih berdasarkan pertimbangan prosesnya lebih cepat, dan tanpa membutuhkan pelarut. Pemanfaatan Bioetahanol dapat digunakan sebagai bahan pencampur bensin sehingga nilai oktannya meningkat dan emisi yang dihasilkan dari bahan bakar bensin menurun, sehingga lebih ramah terhadap lingkungan. Namun di sisi lain penggunaan Bioetanol bersifat korosif, sehingga penggunaan maksimal yang disarankan sebagai bahan campuran adalah $25 \%$.
\end{abstract}

Kata kunci: ampas tebu; bioethanol; pyrolysis.

\section{Pendahuluan}

Tebu (Saccharum officinarum) adalah salah satu sumber pertanian energi biomassa yang paling menjanjikan di dunia, termasuk di Indonesia. Menurut berita yang dirilis Harian Republika (Kamis, 14/8/2014), bahwa Indonesia memiliki lahan tebu seluas sekitar 475.000 hektare dan produksi tebu lebih dari 33 juta ton per tahun. Berdasarkan jumlah produksi tersebut, potensi perolehan ampas tebu di Indonesia sekitar 10 juta ton per tahun, atau sekitar $2,35 \%$ dari total ampas tebu seluruh dunia yang mencapai 424 juta ton per tahun.

Ampas tebu dianggap menjanjikan karena merupakan sumber alternatif ramah lingkungan, masuk kategori sumber energi terbarukan, dan merupakan residu industri yang murah, dengan jumlah melimpah (Mulimani, et.al. 2008 dan ). Selama ini, baru sekitar 30-50\% ampas tebu yang baru termanfaatkan, sisa residu lainnya belum dimanfaatkna secara optimal 
(Saska, 2006). Berton-ton ampas tebu terbuang, padahal 80-90\% dari ampas tersebut mengandung material Vollatile yang akan sangat menguntungkan dalam proses pyrolysis (Mulimani, et.al. 2008).

Tebu memproduksi terutama dua jenis biomassa, Sampah Tebu dan Bagasse (Ampas Tebu). Sampah tebu adalah residu lapangan yang tersisa setelah panen tangkai tebu, sementara ampas tebu adalah residu berserat yang tersisa setelah penggilingan batang tebu, dengan kadar air $45-50 \%$ dan terdiri dari campuran serat keras, dengan parenkim halus dan empulur halus dengan sifat higroskopis tinggi (Zafar, 2018). Ampas tebu terutama mengandung selulosa, hemi selulosa, pentosans, lignin, Gula, lilin, dan mineral (Zafar, 2018 dan Hermiati, dkk. 2010). Jumlah yang diperoleh bervariasi dari $22 \%$ hingga $36 \%$ pada Tebu, tergantung pada porsi serat tebu, kebersihan tebu, dan cara memanen (Zafar, 2018).

Komposisi ampas tebu tergantung pada varietas dan kematangan tebu serta metode panen yang diterapkan dan efisiensi pengolahan Gula. Ampas tebu selain dibakar dalam tungku untuk menghasilkan uap untuk pembangkit listrik, juga dapat digunakan bahan baku untuk produksi bioetanol (Zafar, 2018; saska, 2006; dan Sayou, et.al. 2018). Nilai Bagasse sebagai bahan bakar sangat bergantung pada nilai kalorinya, yang dipengaruhi oleh komposisinya, terutama kandungan airnya dan kandungan sukrosanya (Zafar, 2018).

Kadar air adalah penentu utama dari nilai kalor yaitu rendahnya kadar air, semakin tinggi nilai kalorinya. Proses penggilingan yang baik akan menghasilkan kelembaban rendah sebesar $45 \%$ sedangkan kelembaban $52 \%$ akan menunjukkan efisiensi penggilingan yang buruk. Sebagian besar pabrik memproduksi Bagas dengan kadar air 48\%, dan sebagian besar boiler dirancang untuk membakar ampas tebu dengan kelembaban sekitar 50\%. Bagas juga mengandung kira-kira proporsi serat yang sama (selulosa), komponen-komponennya adalah karbon, hidrogen dan oksigen, beberapa sukrosa (1-2\%), dan abu yang berasal dari materi asing. Kandungan materi asing lebih tinggi dengan pemanenan mekanis dan selanjutnya menghasilkan nilai kalori yang lebih rendah (Zafar, 2018).

Setiap 100 ton tebu yang dihancurkan oleh sebuah pabrik gula, akan menghasilkan hampir 30 ton ampas tebu basah (Zafar, 2018). Ampas tebu sering digunakan sebagai sumber bahan bakar utama untuk pabrik Gula; ketika dibakar ia menghasilkan panas yang cukup dan energi listrik untuk memasok semua kebutuhan pabrik gula. Emisi CO2 yang dihasilkan sama dengan jumlah $\mathrm{CO} 2$ yang diserap tanaman Tebu dari atmosfer selama fase pertumbuhannya, yang membuat proses gas rumah kaca menjadi netral. 
Berdasarkan deskripsi diatas, diketahui bahwa ampas tebu memiliki potensi besar untuk dijadikan sumber energy baru terbarukan dan ramah lingkungan. Pemanfaatan limbah ampas tebu untuk dijadikan bahan pembuatan bioethanol dapat memberikan nilai tambah untuk limbah ampas tebu, yang pada mulanya hanya sampah yang tidak bernilai ekonomis menjadi lebih bernilai ekonomis dan bermanfaat. Oleh karena itu pada artikel ini akan dibahas berbagai cara pengubahan ampas tebu menjadi bioethanol untuk bahan bakar dengan metode pyrolisis dan nilai ekonomi produk bioethanol yang berasal dari ampas tebu.

\section{Metode penelitian}

Pirolisis merupakan metode pemecahan struktur kompleks dalam biomassa lignoselulosa dalam rantai polimer hanya dengan menggunakan panas tanpa pelarut. Memang, pirolisis adalah dekomposisi termal bahan polimer secara langsung tanpa oksigen untuk mendapatkan produk padat, cair, dan gas. Proses ini menjadi penting karena kondisi dapat dioptimalkan untuk meningkatkan produksi tars pyrolytic (Ter), selain produk arang dan gas. Namun, meskipun pirolisis hanya membutuhkan reaktor tunggal dan waktu kontak yang pendek, kemurnian dari produk yang diperoleh umumnya terlalu rendah untuk mengizinkan penggunaan produk tersebut secara langsung, sehingga membutuhkan treatment lanjutan seperti purifikasi, destilasi, atau de-oxygenasi. Terlepas dari kekurangan ini, pirolisis dipilih untuk digunakan dalam penelitian kami karena merupakan proses yang lebih menguntungkan daripada fermentasi karena waktu kontak yang lebih singkat, dan juga fakta bahwa tidak ada pelarut diperlukan (Savou, et.al. 2018).

Ada beberapa tahapan metode pyrolysis dalam mengubah ampas tebu menjadi bioethanol. Tahapan-tahapan tersebut akan dijabarkan sebagai berikut:

\subsection{Deashing method (pre-treatment)}

Metode deashing ini adalah sebuah rangkaian pre-treatment dengan mengkondisikan ampas tebu pada tingkat tertentu. Pada penelitian (Das, P., et.al. 2004) digunakan beberapa jenis cairan untuk membasahi ampas tebu. Hal ini dilakukan untuk mengujikan apakah ada pengaruh terhadap hasil dari bio-oil yang dihasilkan.

Dengan menggunakan metode pengkondisian dari material dengan deashing method dihasilkan bahwa dengan metode ini telah meningkatkan beberapa kandungan komponen yang ada pada pengolahan pada sisa ampas tebu, namun untuk memberikan tingkat yang signifikan masih diperlukan tambahan dari kegiatan lain yaitu dengan mengintegrasikan beberapa perulangan pengujian supaya menghasilkan hasil produk bio-oil yang memiliki 
kandungan viskositas yang lebih rendah. Karena untuk menjaga kestabilan oli diperlukan kandungan $31 \%$ ampas tebu dan 5\% dari ethanol namun jika kandungan lebih kecil dari itu maka tingkat kestabilan oli menurun.

\subsection{Metode torrefaction (pre-treatment)}

Salah satu kendala utama yang dihadapi dalam gasifikasi ampas tebu adalah sifat alami ampas tebu. Dimana memiliki kelembaban tinggi, berserat dan kepadatan rendah. Kendala ini diatasi dengan pemanasan biomassa yang lambat pada kondisi basah atau kering pada tekanan atmosfer selama 1 jam sebelum digunakan sebagai gasifikasi bahan baku. Perawatan ini disebut sebagai torrefaction. Teknologi ini dapat diterapkan untuk meningkatkan sifat-sifat biomassa kering (kapas, prosopis, dan ampas tebu) dengan pemanasan lambat selama 1 jam pada suhu $150-300^{\circ} \mathrm{C}$ pada kondisi atmosfer. Hasil Torrefaction pada bahan padat, kadar air rendah dan kandungan energi yang lebih tinggi dari biomassa mentah telah menunjukkan hasil yang menjanjikan (Patel, et.al. 2011)

Pada penelitian dari Daniyanto dkk. (2014) menunjukkan bahwa hasil dari metode torrefaction ini menunjukkan suhu torrefaction pada $150^{\circ} \mathrm{C}$ cenderung menghasilkan kualitas syn-gas yang lebih baik. Analisis gas juga dilakukan untuk mencari suhu torrefaction yang akan memperoleh kualitas syn-gas yang lebih baik. Proses torrefaction biomassa ampas tebu menggunakan mekanisme dalam miniplant gasifiers seperti yang ditunjukkan pada Gambar 1. Unit gasifier terdiri dari reaktor gasifikasi dengan diameter $20 \mathrm{~cm}$ dan tinggi $80 \mathrm{~cm}$, dilengkapi dengan siklon, kolom pendingin dan vakum pompa. Cyclone digunakan untuk memisahkan entrained solid, sementara kolom pendingin digunakan untuk memisahkan bio-oil dari gas dan pompa vakum untuk menarik udara gasifikasi. Untuk proses pemanasan bagase digunakan oven kedap udara dengan suhu 30$250^{\circ} \mathrm{C}$. 


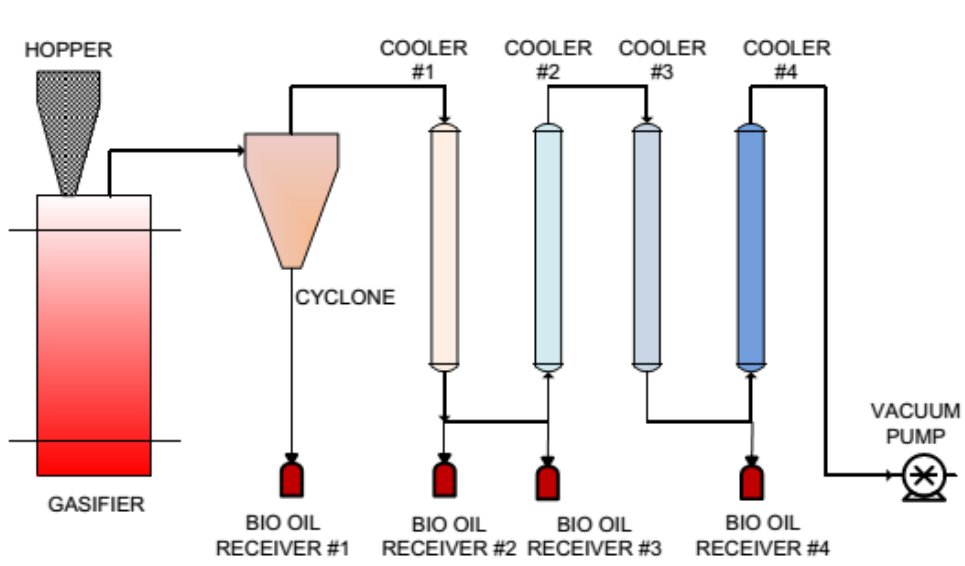

Gambar 1. Miniplant dari kegiatan torrefaction (Sumber: Daniyanto, dkk 2014)

Penggunaan dari torrefaction didasarkan pada penelitian white (2011) bahwa pada kegiatan pyrolisis ditemukan bahwa pada penelitian yang telah dilakukan data untuk melakukan pirolisis kinetis belum memberikan hasil data yang dapat memastikan pengaruh dari kegiatan pyrolisis kinetis karena dari review yang dilakukan bahwa masih ada pengaruh dari reaksi lain yang memerlukan penyelidikan lebih lanjut. Pada review ini juga menyebutkan bahwa salah satu material yang sangat menjanjikan sebagai sumber energi baru adalah dari ampas tebu karena selain dari strukturnya juga pengaruh terhadap lingkungan yang ramah dan memiliki pengaruh yang paling kecil dibanding dengan material lain.

\subsection{Metode Fast-Pyrolisis}

Pirolisis cepat pada suhu menengah dan waktu tinggal uap rendah dikenal sebagai kondisi yang paling sesuai untuk memaksimalkan produk cair dari biomassa. Untuk mencapai tingkat pemanasan yang cepat, reaktor unggun terfluidisasi dan tertahan telah banyak digunakan. Dalam kasus "pirolisis terfluidisasi”, dan yang menarik adalah terdapat partikel uap yang menyebar telah dilaporkan. Vacuum pyrolyser - turbulensi rendah di dalam reaktor pirolisis bergerak dan wadah untuk mencampur yang dikembangkan oleh Pyrovac telah dilaporkan telah mengurangi akumulasi partikel dalam produk yang dapat dikondensasikan. Pirolisis vakum menyediakan waktu tinggal uap rendah yang diperlukan dengan sedikit pengkondisian dalam laju pemanasan yang dapat dicapai dengan cara ini dapat mengurangi produk cair (Das, P., et,al. 2004) 


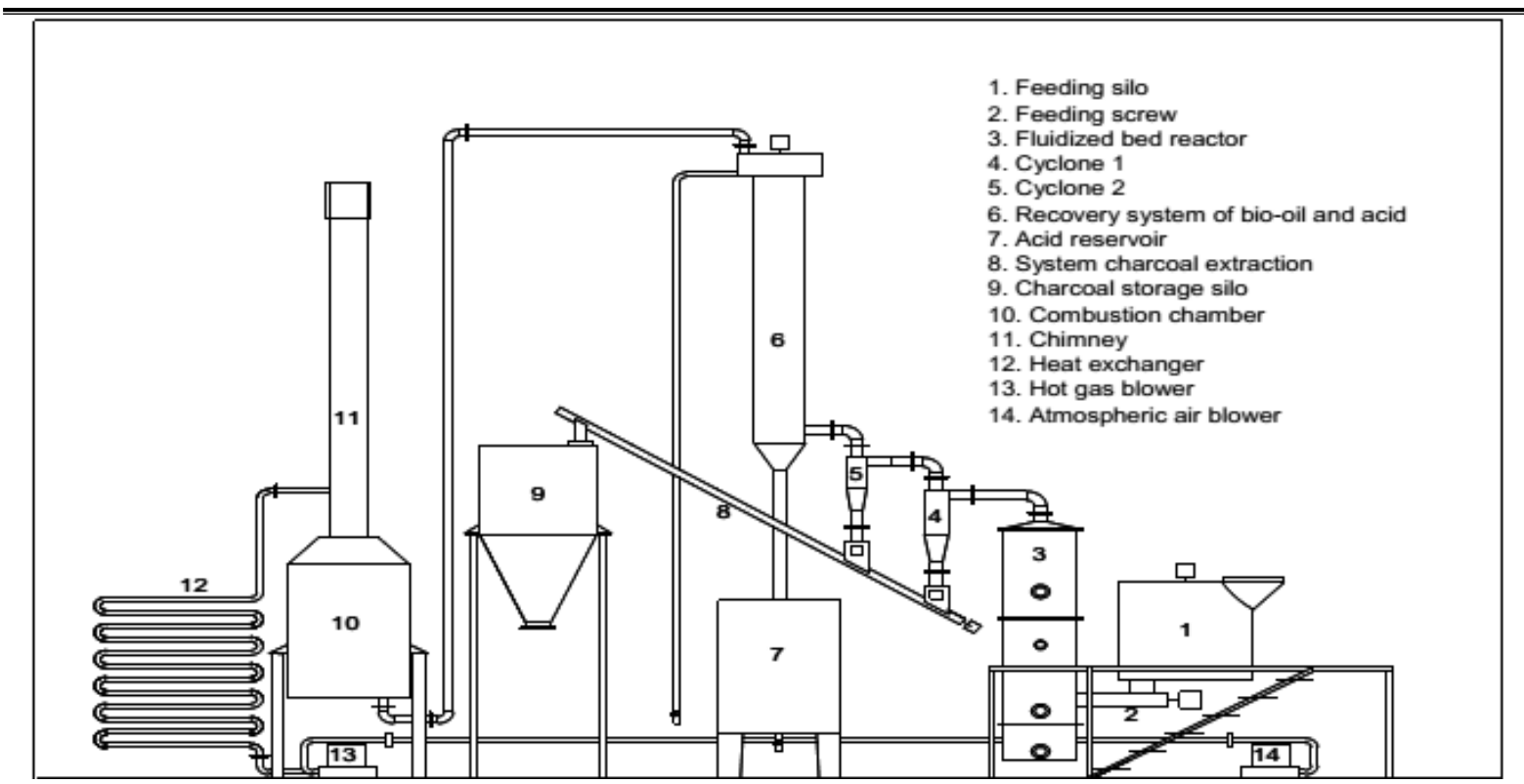

Gambar 2. Salah satu mekanisme dengan fast pyrolisis pada UNICAMP (Sumber: Cortez, et.al. 2010)

\section{Tahapan alur pada fast pyrolisis:}

Biomassa dimasukkan ke dalam silo (1), yang memiliki lubang sekrup (2) yang menyuntikkan biomassa ke reaktor pirolisis cepat dari unggun terfluidisasi (3). Biomassa, ketika bersentuhan dengan dasar reaktor, diuapkan, sehingga menjadi padat (arang), uap (bio-minyak dan asam pyroligneous) dan gas. Arang dipisahkan dalam baterai siklon (4 dan 5) dan disimpan dalam silo (9), asam pyroligneous dan bio-oil dipisahkan dalam kolom pemulihan (6), secara terpisah. Di waduk (7) ekstrak asam diperoleh dan biominyak dikeluarkan dari pintu keluar atas dari kolom pemulihan melalui sistem mekanik berputar. Gas yang tersisa dibakar di ruang bakar (10). Gas-gas ini dapat digunakan sebagai agen fluidizing bed menggunakan penukar panas (12) dan blower gas panas (13). Namun, sejauh ini tes menggunakan udara atmosfer dari blower (14).

Mekanisme pyrolisis yang dilakukan adalah dengan tahapan sebagai berikut:

- Pengumpulan material untuk pyrolisis

Pengumpulan dan pretreatment seluruh tebu tebu dipanen secara manual, tanpa pemisahan antara daun dan tangkai (seluruh tebu) di lahan tebu dekat UNICAMP di Campinas. Pada tahap berikutnya, seluruh tebu di pra-perawatan, dalam langkah yang termasuk memotong, mengeringkan dan menggiling. Proses pemotongan seluruh tebu dilakukan dalam mesin untuk memisahkan, memotong dan menggiling biji-bijian dan makanan ternak. Peralatan yang digunakan dioperasikan dengan pisau dan hammer mill dengan pemisahan mekanis. 
Setelah dipotong-potong, semua bahan diserahkan ke proses pengeringan, yang berlangsung di bawah sinar matahari. Karena itu adalah proses alami, kadar air dicapai dalam urutan 10-15\% (kesetimbangan kelembaban). Kemudian, seluruh material yang kering dan telah terpotong menuju proses penggilingan / penggilingan untuk mengurangi ukuran partikel menjadi diameter rata-rata sekitar 2,0 mm. Pada langkah ini, digunakan peralatan yang sama yang digunakan dalam proses pemotongan; meskipun menggunakan saringan dengan bukaan $5 \mathrm{~mm}$ sebagai gantinya.

- Penentuan komposisi unsur tebu penuh

Perkiraan komposisi unsur dari seluruh tebu dilakukan menggunakan data dari literatur yang berkaitan dengan konstitusi komponennya, secara individual (gula, ampas tebu dan tebu), dengan mempertimbangkan fraksi massa masing-masing komponen. Dalam kasus gula, itu hanya dianggap kontribusi sukrosa, sesuai dengan BNDES dan CGEE (2008), untuk 95\% gula ada di dalam tebu. Dalam pengertian ini, seperti yang digunakan, sebagai rumus kimia sukrosa, rasio $\mathrm{C} 12 \mathrm{H} 22 \mathrm{O} 11$ dengan berat molekul setiap elemen sama dengan: $\mathrm{C}=12 \mathrm{kmol} / \mathrm{kg}, \mathrm{H}=1 \mathrm{kmol} / \mathrm{kg}$ e $\mathrm{O}=16 \mathrm{kmol}$ / kg. Untuk ampas tebu, digunakan data yang dilaporkan oleh Seye et al (2003), dengan komposisi dasar massa dari masing-masing elemen sama dengan: $\mathrm{C}=46,73 \%$, $\mathrm{H}=5,9 \% . \mathrm{N}=0,87 \%$ e $\mathrm{O}=46,5 \%$. Dalam kasus sampah tebu, data yang digunakan disediakan oleh Institute for Technological Research (IPT). Data ini diperoleh dalam tes laboratorium sampel sampah tebu yang digunakan dalam tes pirolisis di pabrik PPR-200. Tes laboratorium dilakukan sesuai dengan Standar American Society untuk Pengujian dan Bahan (ASTM) D 5373-02 (07) dan D 4239-04a. Penentuan jumlah massa masing-masing komponen (gula, ampas tebu dan tebu) di seluruh tebu dilakukan menggunakan data yang disediakan oleh CGEE (2004), di mana di setiap ton bersihnya.

- $\quad$ Tes pirolisis

Tes pirolisis Percobaan dilakukan dengan reaktor yang beroperasi pada 450-470 - $\mathrm{C}$, tekanan rata-rata $120 \mathrm{kPa}$ dan laju aliran udara fluidisasi sekitar $111 \mathrm{~m}$. Dari produk yang dihasilkan di seluruh pirolisis tebu, hanya minyak-bio yang dievaluasi secara kualitatif melalui analisis ultimate dan proksimat. Selain itu, indeks keasaman, kadar air, nilai kalori yang lebih tinggi (HCV) dan kalori yang lebih rendah nilai (LCV) ditentukan.

\subsection{Pengujian untuk Peningkatan komponen tertentu (hasil arang)}


Penggunaan monoammonium fosfat (MAP) atau diammonium phosphate (DAP) sebagai agen untuk mengkatalisasi dan meningkatkan hasil arang dari pirolisis ampas tebu telah dibuktikan dalam penelitian dari Griffin, et.al. (2015). Jika pirolisis dilakukan hingga suhu $400-450^{\circ} \mathrm{C}$ maka hasil arang meningkat dengan konsentrasi aditif, meskipun tingkat peningkatan hasil char menurun pada konsentrasi lebih besar dari 0,1M. Peningkatan hasil arang ini adalah hasil dari aksi asam fosfat dan spesies fosfor lainnya yang mengkatalisasi dehidrasi hemiselulosa, selulosa dan lignin untuk menghasilkan air dan mengurangi evolusi senyawa gas berbasis hidrokarbon. Jika pirolisis dilakukan hingga $700{ }^{\circ} \mathrm{C}$, bagaimanapun, hasil arang dapat melewati maksimum sehubungan dengan konsentrasi aditif. Pada konsentrasi aditif tinggi (yaitu> 0,1 M), aditif dapat dimasukkan ke dalam struktur biomassa dan kemudian berevolusi sebagai senyawa organik-fosfor pada suhu lebih besar dari $450{ }^{\circ} \mathrm{C}$ sehingga mengurangi hasil arang.

\section{Hasil dan pembahasan}

Pengubahan setiap $5 \mathrm{~kg}$ ampas tebu menjadi bioethanol dengan menggunakan metode pyrolysis akan menghasilkan 1 liter bioethanol, dengan harga ampas per kg sebesar Rp. 1000,(Harian Tempo on line, 10/10/2013). Setiap tahun di Indonesia ada sekitar 10 juta ton ampas tebu yang tidak termanfaatkan. Sehingga potensi bioethanol yang dapat diproduksi di Indonesia adalah 2 milyar liter bioethanol per tahun.

Bioethanol dikenal sebagai bahan bakar yang ramah lingkungan, karena bersih dari emisi bahan pencemar. Bioethanol mempunyai nilai oktan yang lebih tinggi dibandingkan dengan premium. Bioethanol apabila dicampur dengan premium dapat meningkatkan nilai oktan, dimana nilai oktan untuk bioethanol $98 \%$ adalah sebesar 115, selain itu mengingat bioethanol mengandung 30\% oksigen, sehingga campuran bio-ethanol dengan gasoline dapat masuk katagorikan high octane gasoline (HOG), dimana campuran sebanyak 15\% bioethanol setara denganpertamax (RON 92) dan campuran sebanyak 24\% bioethanol setara dengan pertamax plus (RON 95). Hal itu menunjukkan bahwa bio-ethanol dapat dimanfaatkan sebagai aditif pengganti MTBE untuk meningkatkan efisiensi pembakaran dan menghasilkan gas buang yang lebih bersih (Wahid, 2006).

Walaupun ethanol/bio-ethanol mempunyai nilai oktan (octane rating) lebih tinggi dan emisi yang lebih bersih dibanding premium, namun ethanol/bioethanol juga mempunyai sifat korosif dan membuat mesin lebih sulit distarter. Sifat korosif ini menyebabkan diperlukannya material yang tahan korosif pada peralatan-peralatan tertentu seperti, tanki bahan bakar, 
karburator, pipa-pipa, karet-karet penyekat dan lain-lain peralatan. Sedangkan kesulitan dalam starter ini memang sulit dihindari, karena temperatur pembakaran sendiri/flash point ethanol yang tinggi sehingga pembakaran secara homogen akan sulit tercapai pada tekanan kompresi di ruang bakar, khususnya pada mobil lama yang menggunakan karburator konvensionil. Oleh karena itu, penggunaan campuran Bioethanol dalam premium dibatasi antara $5-25 \%$ agar kinerja mesin tidak terlalu berbeda, sedangkan pemakaian campuran yang lebih besar harus menggunakan mesin yang sudah dimodifikasi atau mesin yang khusus untuk pemakaian ethanol (Wahid, 2006). Untuk membandingkan sifat fisik, kimia, dan thermal antara bioethanol dan bensin premium adalah sebagaimana tercantum pada table 1 .

Berdasarkan Tabel 1 di atas Wahid (2006) menjelaskan bahwa nilai kalor bioethanol yang lebih rendah dari bensin premium, akan mempengaruhi kinerja mesin. Kendaraan berbahan bakar bioethanol berjarak tempuh 10-30\% lebih rendah dibanding kendaraan berbahan bakar premium. Hal ini disebabkan karena setiap galon ethanol mengandung hanya sekitar $70 \%$ energi yang dikandung oleh setiap galon premium. Hal ini perlu diperhitungkan dalam menghitung nilai ekonomis dari bio-ethanol bila dibandingkan dengan premium, artinya karena jarak tempuh 70\% lebih pendek maka harga jual ethanol harus lebih rendah dari 70\% harga premium agar ethanol dapat bersaing secara ekonomis dengan premium.

Tabel 1. Perbandingan Sifat Thermal, Kimia, dan Fisik Bioetanol dan Premium

\begin{tabular}{|c|c|c|c|c|c|}
\hline No & \multicolumn{2}{|r|}{ Keterangan } & Unit & Ethanol/ & Premium \\
\hline 1 & Sifat & & & & \\
\hline & Thermal & a. Nilai Kalor & (kkal/liter) & 5023,3 & 8308 \\
\hline & & b. Panas penguapan pada $20^{\circ} \mathrm{C}$ & (kkal/liter) & 6,4 & 1,8 \\
\hline & & c. Tekanan uap pada $38^{\circ} \mathrm{C}$ & (Bar) & 0,2 & 0,8 \\
\hline & & d. Angka Oktan Motor & $(\mathrm{MON})$ & 94 & 82 \\
\hline & & e. Angka oktan riset & $(\mathrm{RON})$ & 111 & 91 \\
\hline & & f. Index Cetan & $\left({ }^{\circ} \mathrm{C}\right)$ & 3 & 10 \\
\hline & & g. Suhu pembakaran sendiri & & 363 & $221-260$ \\
\hline & & h. perbandingan nilai bakar & & & \\
\hline & & terhadap premium & & 0,6 & 1 \\
\hline
\end{tabular}

2 Sifat

Kimia

a. Analisi Berat:

$\mathrm{C}$ 
$\mathrm{O}$

$\mathrm{C} / \mathrm{H}$

b. Keperluan udara $(\mathrm{Kg}$

udara/kg bahan bakar)
34,7

4

9
0

6,7

14,8

\section{Sifat}

Fisika
a. berat jenis
b. Titik didik
c. Kelarutan dalam air

$(\mathrm{g} / \mathrm{cm})$

0,8

0,7

$\left({ }^{\circ} \mathrm{C}\right)$

78

32-185

Ya

Tidak

Sumber: Djojonegoro, 1981 dalam Wahid, 2006.

Terkait dengaan emisi yang dihasilkan, pencampuran bioethanol ke bahan bakar bensin premium akan menurunkan jumlah emisi bahan bakar. Secara detail perbandingan emisi bahan pencemar dari campuran Bioetanol dan premium akan disajikan dalam Tabel 2.

Tabel 2. Perbandingan Emisi Bahan Pencemar Dari Campuran Bioetanol Dan Premium

\begin{tabular}{lll}
\hline \multicolumn{1}{c}{ Emisi } & \multicolumn{1}{c}{ E10 } & \multicolumn{1}{c}{ E85 } \\
\hline Carbon Monoxside (CO) & Berkurang 25-30\% & Berkurang 40\% \\
Carbon Dioxside $\left(\mathrm{CO}_{2}\right)$ & Berkurang 10\% & Berkurang 14-102\% \\
Nitrogen Dioxside & Berkurang 5\% & Berkurang 30\% \\
Volatile Organic Compound (VOC) & Berkurang 7\% & Berkurang >30\% \\
Sulfir Dioxides $\left(\mathrm{SO}_{2}\right)$ & Beberapa Pengurangan & Berkurang hingga 80\% \\
Particulates & Beberapa Pengurangan & Berkurang 20\% \\
Aldehides & Meningkat 30-50\% & Tidak cukup data \\
Aromatic (benzene dan butadiene) & Beberapa Pengurangan & Berkurang lebih 50\% \\
\hline
\end{tabular}

Sumber: Wahid, 2006

Dengan gambaran diatas maka dapat dibuktikan bahwa penggunaan bioethanol sebagai aditif untuk menggantikan TEL atau MTBE akan sangat mendukung kebersihan lingkungan karena tingkat emisi GRK rendah dan tidak mengandung bahan beracun maupun zat yang menyebabkan kerusakan Ozon dan memicu pemanasan global, maupun perubahan iklim.

\section{Kesimpulan}


Berdasarkan penjabaran dalam makalah ini dapat disimpulkan bahwa:

1. Ampas tebu memiliki potensi besar untuk dikembangkan menjadi bahan bakar alternatif dan ramah lingkungan, yaitu bioethanol di Indonesia dengan potensi jumlah ampas tebu 10 juta ton per tahun, untuk kapasitas produksi 2 milyar liter bioethanol per tahun.

2. Ada beberapa metode untuk mengubah ampas tebu menjadi bioethanol, namun metode pyrolysis dianggap lebih menguntungkan daripada fermentasi karena waktu kontak yang lebih singkat, dan juga tidak membutuhkan pelarut.

3. Pemanfaatan Bioetahanol dapat digunakan sebagai bahan pencampur bensin sehingga nilai oktannya bertambah dan emisinya menurun, sehingga lebih ramah terhadap lingkungan. Namun di sisi lain Bioetanol bersifat korosif, sehingga penggunaan maksimal yang disarankan sebagai bahan campuran adalah $25 \%$.

\section{Daftar Pustaka}

1. Anonim. 2014. Indonesia Berpotensi Produksi Listrik dari Ampas Tebu. Sumber: https://republika.co.id/berita/ekonomi/bisnis/14/08/14/naamev-indonesia-berpotensiproduksi-listrik-dari-ampas-tebu. Diakses: Jum'at, 21 Desember 2018 Pukul 3:53 WIB

2. Mulimani, HV., Khot, SP., Tippimath, VK., Hallad, NS., and Benni, PK. 2008. Conversion Of Waste Bagasse To Bio-Oil By Pyrolysis And Utilization Of Its Products. PROJECT REFERENCE NO.: 40S_BE_0280. Department Of Mechanical Engineering. Biluru Gurubasava Mahaswamiji Institute Of Technology, Mudhol.

3. Saska, M., and Medina, CM. 2006. Production of fuel ethanol from sugarcane bagasse and sugarcane trash. IX. Congress on Sugar and Sugar Cane Derivatives, Havana, Cuba, June $19-22,2006$

4. Zafar, S. 2018. Energy Potential of Bagasse. Sumber: https://www.bioenergyconsult.com/energy-potential-bagasse/ Diakses: Jum'at, 21 Desember 2018 Pukul 3:53 WIB

5. Sayou, V., Grause, G., Kumagai, S., Saito, Y., Kameda, T., Yoshioka, T. 2018. Pyrolysis of sugarcane bagasse pretreated with sulfuric acid. Journal of the Energy Institute xxx (2018) 1-9

6. Das, P., Ganesh, A., Wangikar, P. 2004. Influence of pretreatment for deashing of sugarcane bagasse on pyrolysis products, Piyali Das. Biomass and Bioenergy 27 (2004) 445-457 
7. Patel, B., Gami, B., and Bhimani, H., 2011, "Improved Fuel Characteristics of Cotton Stalk, Prosopis and Sugar Cane Bagasse Through Torrefaction”, Energ Sust Dev, 15, 372375.

8. Daniyanto, Sutidjan, Deendarlianto, Budiman, A., 2nd International Conference on Sustainable Energy Engineering and Application, ICSEEA 2014. Torrefaction of Indonesian sugar-cane bagasse to improve bio-syngas quality for gasification process. Energy Procedia 68 ( 2015 ) 157 - 166.

9. White, J.E., Catallo, W. J., Legendre, B.L., A Journal of Analytical and Applied Pyrolysis. 2011. Biomass pyrolysis kinetics: A comparative critical review with relevant agricultural residue case studies. Journal of Analytical and Applied Pyrolysis 91 (2011) 1-33.

10. Cortez, LAB., Jordan, RA., Perez, JMM., Baldassin, R., Barbin, DF., 2010. Fast Pyrolysis Test With Whole Sugarcane. BioEng, Tupã, v.4 n.2, p. 96-107

11. Griffin, G.J., L. C. K. Tan, L. K. Ho \& M. Pannirselvam School of Civil, Environmental and Chemical Engineering, RMIT University, Australia. 2015. Conversion of bagasse to char-water fuel by pyrolysis. ISSN 1743-3541 (on-line) WIT Transactions on Ecology and The Environment, Vol 195

12. Wahid, LMA. 2006. Pemanfaatan Bio-Ethanol Sebagai Bahan Bakar Kendaraan Berbahan Bakar Premium. Prospek Pengembangan Bio Fuel Sebagai Substitusi Bahan Bakar Minyak. Pusat Pengkajian Dan Penerapan Teknologi Konversi Dan Konservasi Energi Badan Pengkajian Dan Penerapan Teknologi. ISBN 979-95999-6-2. Halaman:61-72 